\title{
BIOLOGICAL EVALUATION OF THE RATIONALITY OF SOIL USAGE IN AGRICULTURE
}

\author{
S. Yu. Bulyhin, O. L. Tonkha \\ National University of Life and Environmental Sciences of Ukraine \\ 15, Heroyiv Oborony Str, Kyiv 03041, \\ e-mai8l: Oksana16095@gmail.com,s.bulygin@ukr.net
}

Received on February 25, 2018

\begin{abstract}
Aim. To perform biological evaluation of 60-year-long application of different variants of fertilization in terms of the number of microorganisms, transforming the compounds of nitrogen and carbon. Methods. Microbiological methods - determining the number of microorganisms, transforming the organic compounds and nitrogen, statistical processing. Results. It was determined that the application of a crop rotation with legumes and the variant with complete mineral fertilization on meadow-chernozem carbonate soils formed a balanced composition of microbial cenosis and the most optimal conditions for humus accumulation and nitrogen transformation. Conclusions. The microbiological monitoring demonstrated that it is possible to achieve non-degradation development of meadow-chernozem soil at the quasi-stable level in case of applying the 10-field crop rotation with legumes (clover) and complete mineral fertilization.
\end{abstract}

Keywords: ammonifying, amylolytic microorganisms, pedotrophic, humate-decomposing microorganisms, complete mineral fertilization.

DOI: 10.15407 /agrisp5.01.023

\section{INTRODUCTION}

The soil cover of Ukraine has been studied rather well, but the intense process of soil degradation has not been stopped. Approximately a third of arable lands is eroded, about $20 \%$ of organic substances are lost, almost half of all the soils have excessive density, the reserves of nutrients, especially phosphorus and potassium, are decreasing. The main reason of the mentioned problems is underestimation of the actual danger of soil degradation for future generations, lack of understanding of the fact that the fertility of soils is the actual value of arable lands, which requires technological measures, aimed at its preservation [1, 2]. According to the data of the UN Food and Agriculture Organization (FAO), the agricultural activity has resulted in considerable degradation processes. Soil degradation is a relevant problem for Ukraine, directly impacting the fertility of soil and the quality of agricultural products, which brings about economic loss (over USD 6 billion a year) [3]. The solution of problems, related to the management of land resourc-

(C) S. Yu. BULYHIN, O. L. TONKHA, 2018 es, requires the biological monitoring of the rationality of using agrotechnologies.

Microbial cenosis is remarkable for high sensitivity to the changes in the technologies of cultivating crops [4]. A relevant role of soil microorganisms is conditioned by their participation in the formation of soil fertility and, in particular, in the transformation of nutrients in soil (nitrogen and carbon, first and foremost) [5]. Fertilizers (organic and mineral) and soil tillage influence the number and the ratio of different physiological groups of soil microorganisms. The impact of mineral fertilizers on soil biota is of low specificity; it depends on the chemical nature and the dose of introduction [6]. For instance, it was demonstrated in the works [7-10] that the introduction of a considerable amount of mineral fertilizers leads to qualitative and quantitative changes in the microbial complex of typical chernozem, which is accompanied with the simplification of trophic relations and the decrease in biodiversity. The introduction of organic fertilizers on the background of moderate mineral fertilizers under the ecological and biological systems of agriculture leads to the increase in the number of microorganisms by $23 \%$ and $7 \%$ respectively, 


\section{BULYHIN et al.}

as they consume organic nitrogen, and to the decrease of the groups, consuming the mineral nitrogen, in the biological system by up to $36 \%$ [8]. Under these systems, there are changes in the agrobiocenosis towards the decrease in oligotrophicity due to the formation of a smaller number of substances in the soil, which are notable for the latter stages of organic matter mineralization, and the increase in pedotrophs, utilizing the water-soluble fractions of organic matter [8, 9]. In conditions of excessive technological burden, chernozem soils start degrading with acceleration. It is especially true for less stable meadow-chernozem soils. Intense application of modern crop rotations on three fields brought about sharp deterioration of their condition. The problem is getting more pressing. Living matter is a clear reference point of determining the gradient of the soil-formation process.

The aim of the studies was to determine the impact of different fertilization systems in a crop rotation on the number of the main groups of microorganisms, which participate in the transformation of nitrogen and carbon compounds.

\section{MATERIALS AND METHODS}

The biological evaluation of the 60-year-long application of mineral fertilizers in the 10-field crop rotation was conducted in the industrial division of the National University of Life and Environmental Sciences of Ukraine (ID NULES of Ukraine "Agronomic Experimental Station" in conditions of a continuous agronomic experiment of the Chair of Agrochemistry and Quality of Plant Products named after O. I. Dushechkin, which was started in 1956 in a 10-field crop rotation: clover, winter wheat, sugar beet, corn for silo, spring wheat, green peas, winter wheat, sugar beet, corn for grain, barley with clover. The experimental field is located in the Right-Bank Forest-Steppe zone and belongs to the Bila Tserkva agrosoil district. The relief of the area is flat (Kyiv plateau), the relief of the territory is an undulate flat. In addition, the fallow is left in the form of protection belts as absolute control.

The soil of the experimental plot is meadow-chernozem, carbonate, low-humus, heavy loamy, medium clay on forest-like clay. The amount of total humus in soil of the experimental plots was $4.09-4.50 \%$, and on the fallow $-5.50 \%$. The following fertilization variants were studied in the experiment: 1) no fertilizers (control); 2) phosphate fertilizers; 3) phosphate and potassic fertilizers; 4) a single dose of NPK; 5) one-and-a-half dose of NPK. The system of soil tillage was traditional, presupposing moldboard plowing, and there was surface tillage for winter wheat after green peas. The studies of soil were conducted in the $0-10$ and $10-20 \mathrm{~cm}$ layers of soil in May. The selection and keeping of the soil for the study of aerobic microbiological processes in laboratory conditions was performed in accordance with DSTU ISO 10381-6-2001. A comprehensive approach was selected for the evaluation of the processes of microbial transformation of carbon-containing compounds in typical chernozem, which presupposed three stages of implementing the studies: 1 - estimating the agrochemical state of soil; 2 - investigating the quantitative and qualitative composition of the microbial complex, including microorganisms, participating in the transformation of carbon compounds in soil; 3 - determining the biological activity of the microbiota of the meadow-chernozem soil and the direction of the processes of microbial transformation of carboncontaining compounds. The selection of indices for the evaluation of microbial transformation of carbon compounds in soil was based on the following criteria: informative value and high sensitivity of indices, provability of results, high rate of the determination method, application of novel experience of foreign countries and compliance with current regulatory standards in force [6]. Meat-and-peptone agar (MPA) was used to study the total number of microorganisms, decomposing the organic substances; starch-ammonium medium (SAM) - to study the microorganisms, assimilating mineral nitrogen forms. The number of microorganisms, synthesizing melanin, was studied in Czapek's medium at $\mathrm{pH}=5.0$; the ones, decomposing humates in the medium with potassium humate; pedotrophs - in the soil agar.

The methods of registering the colonies of microorganisms in soil and the composition of media were studied according to D. G. Zviagintsev [8]. The results of the number of microorganisms were presented with the number of forming units in $1 \mathrm{~g}$ of absolutely dry soil (CFU/g of soil), taking into account the coefficient of soil humidity [8]. The direction of microbial processes in soil was determined via the evaluation of the following indices: the coefficient of mineralizationimmobilization of nitrogen (evaluated by the ratio of the number of microorganisms, consuming mineral and organic nitrogen) [9]; the coefficient of pedotrophicity (the ratio of the number of pedotrophic microorganisms to MPA) [8]; the coefficient of microbial transformation of organic matter of soil (the ratio of the number of microorganisms to MPA and SAM to the minera- 


\section{BIOLOGICAL EVALUATION OF THE RATIONALITY OF SOIL USAGE IN AGRICULTURE}

lization coefficient) [8]. The statistical processing and mathematical analysis of the results of studies were conducted using MS Excel 10.0, STATISTICA 7.0 and QIIME 1.7.0 programs.

\section{THE RESULTS OF INVESTIGATIONS}

Nitrogen cycle consists of the process of its microbial fixing from the atmosphere and the introduction of the bound nitrogen into a small biological circulation with the destruction of nitrogen-containing organic compounds to ammonium (ammonification), oxidation of ammonium to nitrates (nitrification), subsequent reduction to free nitrogen (denitrification), which is released into the atmosphere again. Microorganisms play the main role in the transformation of nitrogen in soil [5].

In our studies the number of ammonifying and amylolytic microorganisms (Table 1) in the meadowchernozem carbonate soil depended on the variant of fertilization and decreased with depth. For instance, the highest number of microorganisms, decomposing the organic forms of nitrogen in all the variants of the studies, was obtained in the root-containing layer of $0-10 \mathrm{~cm}$, with further decrease by $14-87 \%$ in the 10-20 cm layer. A similar regularity was obtained for the number of amylolytic microorganisms, here their decrease in the 10-20 $\mathrm{cm}$ layer compared to $0-10 \mathrm{~cm}$ layer was $10-67 \%$. The highest number of ammoni-fying microorganisms was obtained in the variant with 1.0 dose of NPK which is related to the saturation of soil with nitrogen. While evaluating the degree of saturation by the number of ammonifiers using the method of D. G. Zviagintsev [7], one should note that all the fertilization variants are characterized as poor ones, except for 1.0 dose of NPK - a very rich one.

Therefore, the situation with humus accumulation is not very good in all the fertilization variants, except for 1.0 dose of NPK. The highest number of microorganisms, using mineral forms of nitrogen in the meadow-chernozem soil, was obtained using PK, 1.5 dose of NPK and the fallow. It indicates the intensity of the mineralization processes using the abovementioned variants of fertilization.

In the opinion of Yu. P. Moskalevska, M. V. Patyka [6], H.O. Iutynska [9], I. D. Prymak [10], the processes of mineralization of humic substances are conditioned by biochemical activity of the specific microflora - humate-decomposing ones, including the microorganisms, capable of using carbon of the cyclic and heterocyclic bonds, which are most resistant to decomposition. Other researchers deny the specialization of microorganisms in humus decomposition and refer these processes to the activity of all the soil microorganisms [8]. According to the data of H. O. Iutynska

Table 1. The number of ammonifying and amylolytic microorganisms in the meadow-chernozem soil in the crop rotation with sugar beet after winter wheat*

\begin{tabular}{l|c|c|c}
\hline $\begin{array}{c}\text { Fertilization } \\
\text { variant }\end{array}$ & $\begin{array}{c}\text { Soil layer, } \\
\mathrm{cm}\end{array}$ & $\begin{array}{c}\text { Ammonifying } \\
\text { microorganisms } \\
\text { (mln CFU/g of soil) }\end{array}$ & $\begin{array}{c}\text { Amylolytic } \\
\text { microorganisms } \\
\text { (mln CFU/g of soil) }\end{array}$ \\
\hline No fertilizers (control) & $0-10$ & $2.54 \pm 0.18$ & $6.32 \pm 0.50$ \\
P & $10-20$ & $1.76 \pm 0.11$ & $4.32 \pm 0.34$ \\
PK & $0-10$ & $3.25 \pm 0.27$ & $10.6 \pm 0.43$ \\
1.0 dose of NPK & $10-20$ & $2.81 \pm 0.24$ & $15.25 \pm 0.45$ \\
1.5 dose of NPK & $0-10$ & $3.03 \pm 0.23$ & $11.16 \pm 0.64$ \\
Fallow & $10-20$ & $2.76 \pm 0.17$ & $9.74 \pm 0.37$ \\
& $10-20$ & $26.02 \pm 1.51$ & $7.56 \pm 0.17$ \\
\end{tabular}

* ID NULES of Ukraine "Agronomic Experimental Station" 
BULYHIN et al.

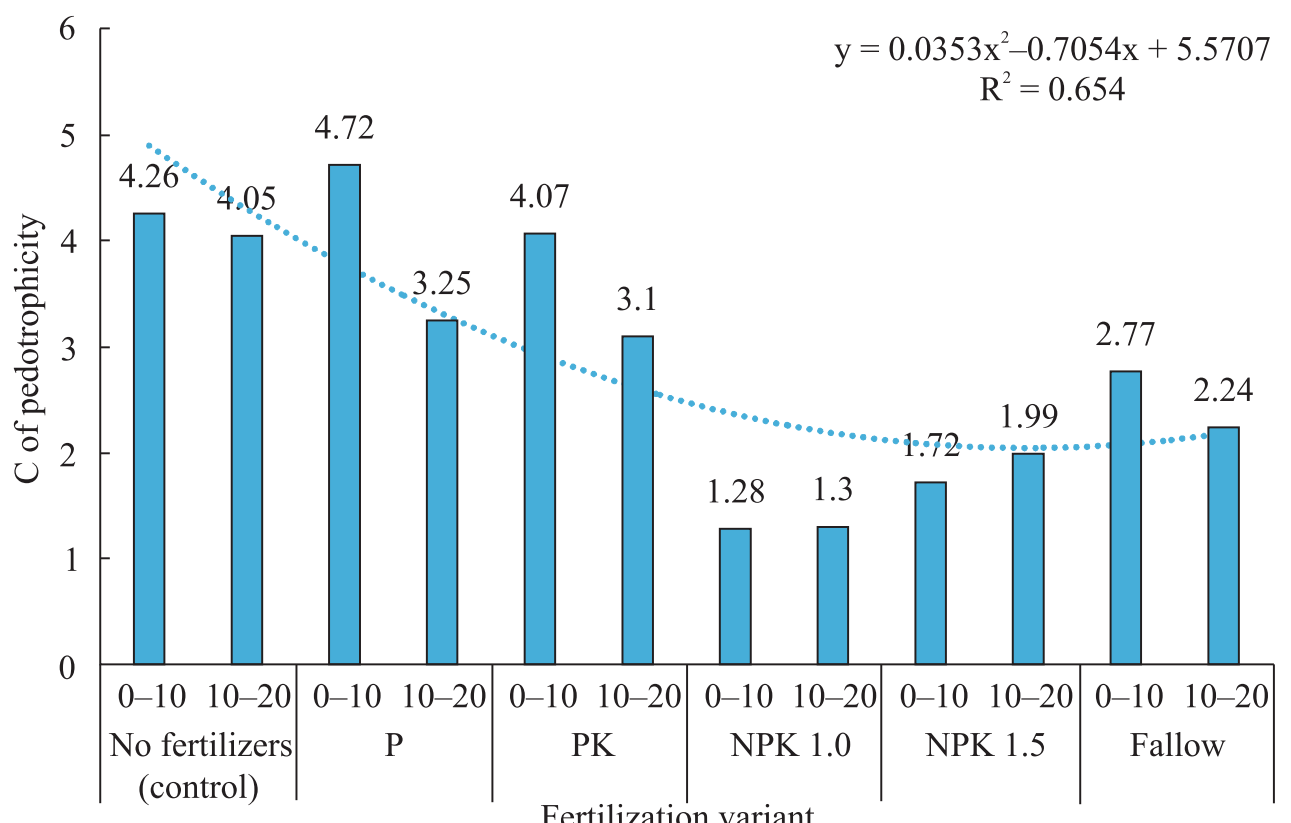

Fig. 1. The coefficient of pedotrophicity in the meadow-chernozem carbonate soil under different variants of fertilization

[9], the decomposition of peripheral chains of humus molecules involves the participation of pedotrophic microorganisms, while deep destruction is performed by humate-decomposing ones. The number of pedotrophs, utilizing water-soluble fractions of organic matter and microorganisms, conducting deep destruction of nuclear aromatic components of humus, is presented in Table 2.
The results of investigations demonstrated that the highest number of pedotrophic microorganisms was observed in case of a single dose of mineral fertilizers, and the lowest one - in case of one and a half dose. The highest values in terms of the number of humatedecomposing microorganisms were obtained while using phosphate and potassic fertilizers both in $0-10$ and $10-20 \mathrm{~cm}$ layers.

Table 2. The number of pedotrophic and humate-decomposing microorganisms depending on the fertilization variants in the meadow-chernozem carbonate soil

\begin{tabular}{l|c|c|c}
\hline $\begin{array}{c}\text { Fertilization } \\
\text { variant }\end{array}$ & $\begin{array}{c}\text { Soil layer, } \\
\mathrm{cm}\end{array}$ & $\begin{array}{c}\text { Pedotrophic } \\
\text { microorganisms, } \\
\text { mln CFU/g }\end{array}$ & $\begin{array}{c}\text { Humate-decomposing } \\
\text { microorganisms, } \\
\text { mln CFU/g }\end{array}$ \\
\hline No fertilizers (control) & $0-10$ & $10.79 \pm 1.87$ & $2.39 \pm 0.07$ \\
& $10-20$ & $7.12 \pm 0.63$ & $1.19 \pm 0.08$ \\
P & $0-10$ & $15.34 \pm 2.13$ & $1.88 \pm 0.12$ \\
PK & $10-20$ & $9.12 \pm 1.52$ & $3.28 \pm 0.06$ \\
NPK 1.0 & $0-10$ & $12.34 \pm 1.56$ & $2.74 \pm 0.36$ \\
NPK 1.5 & $10-20$ & $8.56 \pm 0.46$ & $2.63 \pm 0.2$ \\
Fallow & $0-10$ & $33.3 \pm 2.89$ & $1.19 \pm 0.07$ \\
& $10-20$ & $18.43 \pm 1.13$ & $2.11 \pm 0.08$ \\
\end{tabular}




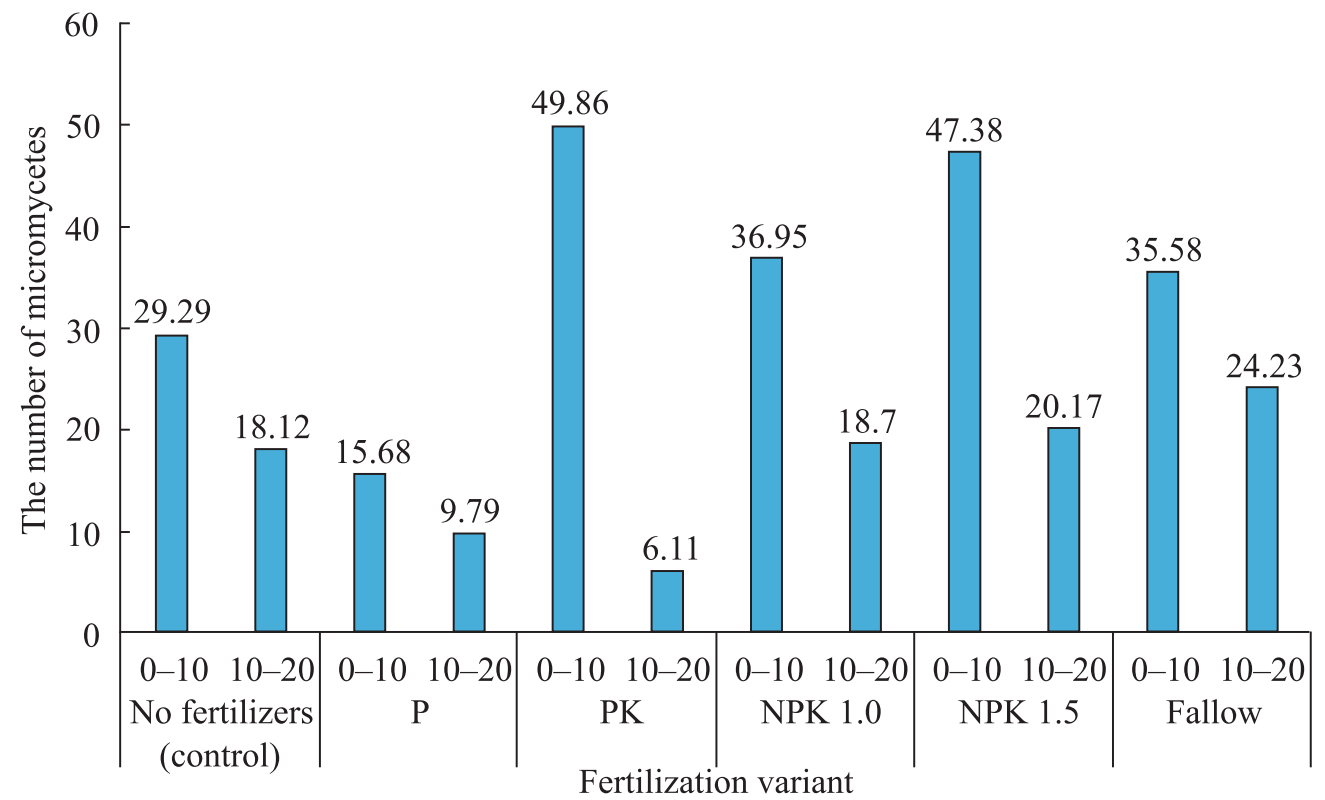

Fig. 2. The number of micromycetes in the meadow-chernozem carbonate soil depending on fertilization, thousand CFU

The coefficient of pedotrophicity indicates the degree of consumption of organic matter (Fig. 1). According to this index in the control and in case of the introduction of phosphate (variant $\mathrm{P}$ ), phosphate and potassic $(\mathrm{PK})$ fertilizers $(\mathrm{Cp} .=3.10-4.72)$, there is development of autochtonous microbiota in the meadow-chernozem soil and the mineralization processes from the total fund are increased.

The most optimal conditions, according to the trend line, are seen in case of one and a half dose of mineral fertilizers. In terms of the number of humate-decomposing microorganisms, the lowest values and the best conditions were obtained under clover. The worst conditions were in the field under sugar beet No. 2, which had 2.1-5.2 times more humate-decomposing microorganisms compared to the field with clover.

The number of micromycetes in the meadow-chernozem carbonate soil depending on the fertilization is presented in Fig. 2.

The highest number of micromycetes in the $0-20 \mathrm{~cm}$ soil layer was obtained at the one-and-a-half dose of mineral fertilizers, with other values in the descending order: fallow - 1.0 NPK - PK - control - P.

\section{CONCLUSIONS}

The optimal conditions for humus accumulation and nitrogen transformation are created on the fallow and

Table 3. The number of pedotrophic and humate-decomposing microorganisms under different crops in the meadow-chernozem carbonate soil

\begin{tabular}{|c|c|c|c|}
\hline $\begin{array}{c}\text { Fertilization } \\
\text { variant }\end{array}$ & $\begin{array}{c}\text { Soil layer, } \\
\mathrm{cm}\end{array}$ & $\begin{array}{c}\text { Pedotrophic } \\
\text { microorganisms, } \\
\text { mln CFU/g }\end{array}$ & $\begin{array}{l}\text { Humate-decomposing } \\
\text { microorganisms, } \\
\text { mln CFU/g }\end{array}$ \\
\hline No fertilizers (control), under sugar beet No. 2 & $\begin{array}{r}0-10 \\
10-20\end{array}$ & $\begin{array}{r}10.79 \pm 1.87 \\
7.12 \pm 0.63\end{array}$ & $\begin{array}{l}2.39 \pm 0.07 \\
1.19 \pm 0.08\end{array}$ \\
\hline No fertilizers (control) under clover & $\begin{array}{r}0-10 \\
10-20\end{array}$ & $\begin{array}{r}13.73 \pm 1.02 \\
9.11 \pm 0.74\end{array}$ & $\begin{array}{l}0.61 \pm 0.07 \\
0.42 \pm 0.04\end{array}$ \\
\hline 1.5 NPK, under clover & $\begin{array}{r}0-10 \\
10-20\end{array}$ & $\begin{array}{l}18.5 \pm 0.84 \\
8.44 \pm 0.51\end{array}$ & $\begin{array}{l}0.76 \pm 0.06 \\
0.58 \pm 0.04\end{array}$ \\
\hline No fertilizers (control), under sugar beet No. 1 & $\begin{array}{r}0-10 \\
10-20\end{array}$ & $\begin{array}{r}14.46 \pm 1.45 \\
9.70 \pm 0.64\end{array}$ & $\begin{array}{l}1.16 \pm 0.03 \\
0.81 \pm 0.07\end{array}$ \\
\hline
\end{tabular}




\section{BULYHIN et al.}

in the variant with complete mineral fertilization. The use of one-and-a-half dose of fertilizers enhanced the mineralized processes in soil 1.2-1.4 times compared to the single dose. The highest number of pedotrophic microorganisms was observed in case of a single dose of mineral fertilizers, and the lowest one - in case of one-and-a-half dose. The highest value in terms of the number of humate-decomposing microorganisms were obtained while using phosphate and potassic fertilizers both in $0-10$ and $10-20 \mathrm{~cm}$ layers. Compared to clover, 2.1-5.2 times more humate-decomposing microorganisms are formed in the field under sugar beet No. 2. The application of the 10-field crop rotation with legumes (clover) and complete mineral fertilizers for 60 years ensured non-degradation development of the meadowchernozem soil at the quasi-stable level.

\section{Біологічна експертиза раціональності використання грунту в агрокультурі}

С. Ю. Булигін, О. Л. Тонха,

Національний університет біоресурсів і природокористування України, 03041, Київ, Вул. Г. Оборони 15 ,

e-mail: Oksana16095@gmail.com, s.bulygin@ukr.net

Мета. Провести біологічну експертизу 60-ти річного застосування різних варіантів удобрення щодо чисельності мікроорганізмів, які трансформують сполуки нітрогену і карбону. Методи. Мікробіологічні визначення чисельності мікроорганізмів, які трансформують органічні сполуки та нітроген, статистичні. Результати. Встановлено, що на лучно-чорноземних карбонатних грунтах застосування сівозміни з бобовими культурами та варіанту 3 повним мінеральним удобренням формує збалансований склад мікробного ценозу і найбільш оптимальні умови для накопичення гумусу і трансформації азоту. Висновки. Мікробіологічний моніторинг показав, що бездеградаційного розвитку лучно-чорноземного грунту на квазістабільному рівні можна досягти за умови застосування 10пільної сівозміни з бобовими культурами (конюшиною) та повного мінерального удобрення.

Ключові слова: амоніфікуючі, амілолітичні мікроорганізми, педотрофні, гуматрозкладаючі мікроорганізми, повне мінеральне удобрення.

Биологическая экспертиза рациональности использования почвы в агрокультуре

С. Ю. Булыгин, О. Л. Тонха

Национальный университет биоресурсов и природопользования Украины, 03041, Киев, Ул. Г. Обороны 15,

e-mail: Oksana16095@gmail.com, s.bulygin@ukr.net
Цель. Провести биологическую экспертизу 60-летнего применения различных вариантов удобрения на численность микроорганизмов, которые трансформируют соединения азота и углерода. Методы. Микробиологические - определение численности микроорганизмов, которые трансформируют органические соединения и азот, статистические. Результаты. Установлено, что на лугово-черноземных карбонатных почвах введение севооборота с бобовыми культурами и применение полного минерального удобрения формируют сбалансированный состав микробного ценоза и наиболее оптимальные условия для накопления гумуса и трансформации азота. Выводы. Микробиологический мониторинг показал, что бездеградацийного развития лугово-черноземной почвы на квазистабильном уровне возможно достигнуть при условии ведения 10-польного севооборота с бобовыми культурами (клевером) и полного минерального удобрения.

Ключевые слова: аммонификаторы, амилолитические микроорганизмы, педотрофные, гуматразлагающие микроорганизмы, полное минеральное удобрение

\section{REFERENCES}

1. World Development Indicators, Data Bank, 2015; http:// databank.worldbank.org/data

2. Acs S, Borodina O, Gomez-y-Paloma S, Kharchenko $A$. Ukraine's agriculture: potential for expanding grain supply. Economic and institutional challenges. European Union. 2013:58 p. https://ec.europa.eu/jrc/en/publication/eur-scientific-and-technical-research-reports/ ukraine-s-agriculture-potential-expanding-grain-supplyeconomic-and-institutional-challenges

3. Integrating Environment into Agriculture and Forestry Progress and Prospects in Eastern Europe and Central Asia, County Review, World Bank. 2008:96 p. https:// openknowledge.worldbank.org/handle/10986/6551

4. Kurdish IK. Role of microorganisms in the restoration of soil fertility. Agricultural microbiology: Interdepart. themat. scient. coll. Chernihiv, 2009;9:7-32.

5. Kudeyarov $V N$. Nitrogen cycle in soil and efficiency of fertilizers. M.: Nauka. 1989:214 p.

6. Moskalevska YuP, Patyka MV. Functional diversity of microbiota of typical chernozem while cultivating beet. Coll. of scient. works of the Uman National Horticulture University. 2014;85:47-55.

7. Zviagintsev $D G$. Role of microorganisms in biogenetic functions of soils. Structural and functional role of soil in biosphere. M.: GEOS. 1999:113-21.

8. Zviagintsev DG. Biology of soils and their diagnostics. Problems and methods of biological diagnostics and indication of soils. M.: Nauka. 1976:175-90.

9. Iutynska GO. Soil microbiology: Textbook / GO Iutynska. - K.: Aristey, 2006:284 p. 


\section{BIOLOGICAL EVALUATION OF THE RATIONALITY OF SOIL USAGE IN AGRICULTURE}

10. Prymak I, Bokancha A. The influence of deep autumn plowing on microbiology processes in typical black soil and on productivity of crops rotation in the central Forest-Steppe zone of Ukraine. Sci. Bull. Uzhgorod Univ. (Ser. Biol.). 2009;26:220-4.

11. Pukhova NYu, Verkhovtseva NV, Larina GE. Structure of microbial community of alkali chernozem depending on the anthropogenic burden. Problems of agrochemistry and ecology. 2011;(4):42-7.

12. Tonkha OL, Balaev AD, Pikovska OV. Formation of microbial complex of regraded chernozem under different fertilization systems. Scientific bulletin of NUBiP of
Ukraine. Series: Agronomy. http://journals.nubip.edu.ua/ index.php/Agronomija/article/viewFile/9675/8652

13. Taylor JP, Wilsona B, Millsb MS, Burns RG. Comparison of microbial numbers and enzymatic activities in surface soils and subsoils using various techniques. Soil Biology and Biochemistry. 2002;34(3):387-401.

14. Tikhonenko DG, NovosadKB, GavvaDV. Microbiological plasma transformation in different biogeocenoses in Forest-Steppe soils of Ukraine. Proc. Int. Symp. on Soil Quality and Management of World Mollisols. China: Northeast Forestry University Press. 2010:216-17. 